\title{
Analisis pengaruh PDRB dan jumlah penduduk terhadap Pendapatan Asli Daerah Kabupaten Kerinci
}

\author{
Afdhal Hendri Saldi*; Zulgani; Nurhayani \\ Prodi Ekonomi Pembangunan, Fak.Ekonomi dan Bisnis, Universitas Jambi \\ *E-mail korespondensi: afdhalhendri.saldi@gmail.com
}

\begin{abstract}
This study aims to analyze the effect of GRDP and population on Regional Original Income (PAD). The analytical method used is multiple linear regression with Ordinary Least Square (OLS) 2006-2020. The results of this study indicate that the development of Regional Original Income (PAD) in Kerinci Regency has increased except for 2009, 2012, 2017, and 2019 with an average PAD of Rp. Forty-seven thousand two hundred twenty million per year, the development of GRDP in Kerinci Regency has increased continuously except in 2008 with an average GRDP of Rp. 5,907.25 billion per year, and the average population growth in Kerinci Regency is 245,932 people per year. As well as the results of the analysis of factors that affect original regional income in Kerinci Regency, simultaneously the GRDP and population variables have a significant effect on Regional Original Income and partially GRDP is having a considerable impact number of residents has no substantial effect.
\end{abstract}

Keywords: PDRB, Population, PAD

\begin{abstract}
Abstrak
Penelitian ini bertujuan untuk menganalisis pengaruh PDRB dan jumlah penduduk terhadap Pendapatan Asli Daerah (PAD). Metode analisis yang digunakan adalah regresi linier berganda dengan Ordinary Least Square (OLS) tahun 2006-2020. Hasil dari penelitian ini menunjukan bahwa, Perkembangan Pendapatan Asli Daerah (PAD) di Kabupaten Kerinci mengalami peningkatan kecuali tahun 2009, 2012, 2017 dan 2019 dengan rata-rata PAD sebesar Rp. 47.220 Juta pertahun, perkembangan PDRB di Kabupaten Kerinci mengalami peningkatan secara terus menerus kecuali tahun 2008 dengan rata-rata PDRB sebesar Rp. 5.907,25 Milyar pertahun dan perkembangan jumlah penduduk di Kabupaten Kerinci rata-rata sebesar 245.932 jiwa pertahun. Serta Hasil analisis faktor yang mempengaruhi pendapatan asli daerah di Kabupaten Kerinci, secara simultan variabel PDRB dan jumlah penduduk berpengaruh signifikan terhadap Pendapatan Asli Daerah dan secara parsial PDRB berpengaruh signifikan dan jumlah penduduk tidak berpengaruh signifikan.
\end{abstract}

Kata kunci : PDRB, Jumlah penduduk, PAD

\section{PENDAHULUAN}

Pembangunan nasional yang dilandasi dengan cita-cita dan tujuan yang besar tentu harus dilaksanakan dengan beberapa kebijakan, salah satunya adalah dengan cara melaksanakan otonomi daerah kebijakan, salah satunya adalah dengan cara melaksanakan otonomi daerah dan desentralisasi fiskal. Tujuan dari pelaksanaan desentralisasi adalah 
untuk memberikan pelayanan publik yang lebih baik serta menciptakan proses pengambilan keputusan publik yang lebih demokratis. Salah satu kebijakan yang diambil oleh pemerintah adalah dengan melaksanakan otonomi daerah dan desentralisasi administrasi, desentralisasi fiskal, desentarilasasi ekonomi.

Pelaksanaan desentralisasi diwujudkan melalui pemberian bantuan dalam bentuk transfer dari pemerintah pusat kepada pemerintah daerah. Dalam pelaksanaannya kebijakan desentralisasi memiliki arti penyerahan wewenang pemerintah pusat kepada daerah otonom,kalau dulu untuk mengambil keputusan harus menunggu petunjuk dan pengarahan dari permerintah pusat dalam bentuk usulan-usulan strategis, dengan berlakunya kebijakan desentralisasi dengan memberikan keleluasaan pemerintah daerah untuk menjalankan roda pemerintahan dan bertanggung jawab akan pelaksaan pembangunan di daerah sesuai peraturan yang berlaku dalam penyelenggaraan pemerintah di daerah memlalui Undang-Undang No or 32 tahun 2004 tentang pemerintah daerah dan Undang-Undang Nomor 33 tahun 2004 tentang perimbangan keuangan pusat dan pemerintah daerah.

Pendapatan asli daerah atau yang selanjutnya disebut PAD merupakan penerimaan yang diperoleh daerah dari sumber-sumber daerah dalam wilayahnya sendiri yang dipungut berdasarkan peraturan daerah sesuai dengan peraturan daerah atau peruundang-undangan yang berlaku. Sektor pendapatan daerah memegang peranan yang sangat penting, karena melalui sector ini dapat dilihat sejauh mana suatu daerah dapat membiayai kegiatan pemerintah dan pembangunan daerah (Baldric, 2017). Pendapatan asli daerah (PAD) bersumber dari pendapatannya yaitu pajak daerah, retribusi daerah, hasil pengelolaan kekayaan yang dipisahkan, lain-lain pendapatan asli daerah yang sah. Pendapatan asli daerah dikatakan baik untuk memenuhi pembiyaan pembangunan daerahnya apabila pencapaian presentasenya melebihi $70 \%$ dari total penerimaan PAD (Carunia, 2017). Berdasarkan teori pengeluaran pemerintah yang menjelaskan bahwa pembelanjaan pemerintah terhadap berbagai kegiatan pembangunan akan meningkatkan pengeluaran agregat dan mempertinggi tingkat kegiatan ekonomi negara (Sukirno, 2006). maka jika dikaitkan dengan pembelanjaan pemerintah daerah yang tercermin dalam realisasi belanja APBD, semakin besar belanja pemerintah daerah maka semakin besar juga dampaknya terhadap perekonomian daerah (Darise, 2006).

Kabupaten kerinci merupakan salah satu kabupaten yang berada di Provinsi Jambi yang mana mengalami masalah tentang masih rendahnya kemampuan daerah dalam mendapatkan pendanaan sehingga dibutuhkan upaya menggali potensi pendapatan yang diperoleh daerah. Meskipun PAD kabupaten kerinci dari tahun 2011 sampai 2020 terlihat adanya kenaikan,seperti yang dapat dilihat dalam tabel 1:

Tabel 1. Pendapatan asli daerah, PDRB dan jumlah penduduk Kabupaten Kerinci

\begin{tabular}{cccc}
\hline Tahun & $\begin{array}{c}\text { PAD } \\
\text { (Juta Rupiah) }\end{array}$ & $\begin{array}{c}\text { PDRB (Milyar } \\
\text { Rupiah) }\end{array}$ & $\begin{array}{c}\text { Jumlah Penduduk } \\
\text { (Jiwa) }\end{array}$ \\
\hline 2016 & 80.850 & $8.052,84$ & 235.802 \\
2017 & 75.214 & $8.875,71$ & 236.782 \\
2018 & 80.481 & $9.408,04$ & 237.791 \\
2019 & 42.421 & $9.912,47$ & 238.682 \\
\hline 2020 & 81.737 & $10.447,13$ & 239.606 \\
\hline
\end{tabular}

Sumber: Badan Pusat Statistik, 2021 
Berdasarkan Tabel 1 disimpulkan bahwa tingkat PAD di Kabupaten Kerinci mengalami fluktuasi dari tahun ke tahun. Pendapatan Asli Daerah Kabupaten Kerinci pada tahun 2017 sebesar Rp. 75.214.000.000 mengalami penurunan dari tahun sebelumnya yang mana pendapatan asli daerah kabupaten kerinci tahun 2016 sebesar Rp. 80.850.000.000, pendapatan asli daerah kabutan kerinci juga mengalami penurunan yg signifikan pada tahun 2019 sebesar Rp. 42.421.000.000 dibandingkan pada tahun 2018 yang sebesar Rp. 80.481.000.000. Namun jumlah pendapatan tersebut belum mampu membiayai seluruh kegiatan perekonomian di Kabupaten Kerinci terutama di bidang pembangunan infrastruktur dan penyediaan layanan publik bagi peningkatan kesejahteraan masyarakat kerinci, salah satu cara yang harus dilakukan pemerintah Kabupaten Kerinci badan usaha daerah serta penerimaan lainnya yang sah guna meningkatkan kemampuan keuangan daerah Kabupaten Kerinci dalam menjalankan roda perekonomian daerah. Pendapatan Asli Daerah Kabupaten Kerinci juga berkaitan dengan PDRB yang merupakan jumlah nilai barang dan jasa akhir yang dihasilkan oleh seluruh unit ekonomi. Keterkaitan tersebut dapat dilihat dengan kesimpulan bahwa dengan semakin tingginya PDRB yang diperoleh maka akan menambah penerimaan pemerintah. Dari tahun ke tahun PDRB Kabupaten Kerinci terus meningkat hal ini menunjukkan Kabupaten Kerinci mampu untuk berproduksi dalam suatu perekonomian dan ini ditunjukan oleh peningkatan PDRB dari tahun 2016 hingga 2020 di Kabupaten Kerinci.

Produk Domestik Regional Bruto (PDRB) adalah nilai dari seluruh barang dan jasa yang diproduksi dalam waktu satu tahun di suatu wilayah tertentu tanpa membedakan kepemilikan faktor produksi, tapi lebih memerlukan keberadaan faktor produksi yang digunakan dalam proses produksi itu, PDRB merupakan salah satu pencerminan kemajuan ekonomi suatu daerah. Kenaikan PDRB akan menyebabkan pendapatan daerah dari sektor pajak dan retribusi meningkat. Hal tersebut berdampak pada peningkatan PAD di daerah tersebut salah satu cara untuk melihat kemajuan ekonomi adalah dengan mencermati nilai pertumbuhan PDRB. Pertumbuhan ekonomi diukur berdasarkan nilai PDRB atas dasar harga konstan, karena nilai PDRB ini tidak dipengaruhi oleh perubahan harga, sehingga 17 perubahan yang diperoleh merupakan perubahan riil yang tidak dipengaruhi oleh fluktuasi harga (Makdalena, 2015). PDRB Kabupaten Kerinci tahun 2016 sampai 2020 mengalami peningkatan secara terus menerus. Terlihat pada tahun 2017 PDRB di Kabupaten Kerinci sebesar Rp. 8.875,71 milyar yang meningkat dari tahun 2016 yang sebesar Rp. 8.052,84 milyar, begitupula hingga tahun 2020 PDRB di Kabupaten mencapai Rp. 10.447,13 milyar. Produk Domestik Regional Bruto (PDRB) merupakan gambaran perekonomian secara menyeluruh di daerah. Produk Domestik Regional Bruto (PDRB) memberikan dampak langsung pada perolehan pendapatan daerah. Dengan meningkatnya PDRB maka akan menambah penerimaan pemerintah daerah yang dapat digunakan untuk membiayai program-program pemerintah atau pembangunan sarana dan prasarana, sehingga dapat meningkatkan pelayanan kepada masyarakat yang diharapkan akan dapat meningkatkan produktivitasnya.

Begitupula dengan jumlah penduduk Hertanto dan Jaka (2011) menjelaskan bahwa jumlah penduduk pada tingkat moderat pada dasarnya positif dan bermanfaat bagi perkembangan ekonomi baik bagi Negara maju maupun Negara berkembang. Semakin banyak orang maka semakin banyak yang mempunyai bakat dan ide kreatif dalam perkembangan teknologi tenaga ahli dengan meningkatnya jumlah penduduk mempengaruhi penerimaan pendapatan daerah terhadap barang atau jasa. Pertumbuhan penduduk merupakan salah satu hal yang dibutuhkan dan bukan suatu masalah melainkan 
sebagin unsur penting yang dapat memacu pembangunan dan pertumbuhan ekonomi. Meningkatnya jumlah penduduk yang memiliki kemampuan yang produktif tentu dapat mengembangkan kegiatan produksi di Daerahnya, maka dapat meningkatkan perluasan adanya usaha-usaha industri-industri baru di sektor produksi.

Dengan dibukanya usaha-usaha baru tentu akan membuka kesempatan kerja yang akan berdampak pada masyarakat sekitar bahkan akan membuka kesempatan pada peningkatan PAD di suatu daerah. Berdasarkan hal-hal yang telah dipaparkan sebelumnya, maka tujuan penelitian ini adalah 1) mengetahui perkembangan PAD, PDRB dan jumlah penduduk di Kabupaten Kerinci tahun 2006-2020, 2) Menganalisis pengaruh PDRB dan jumlah penduduk terhadap PAD Kabupaten Kerinci.

\section{METODE}

Penelitian ini menggunakan data sekunder periode 2006-2020. Data yang digunakan berupa PAD, PDRB dan jumlah penduduk yang berasal dari BPS dan Kabupaten Kerinci dalam angka. Pengolahan data dilakukan dengan mengkombinasikan analisis deskriptif dan pendekatan kuantitatif dengan regresi linear berganda. Dan Untuk menjawab rumusan masalah yang kedua adalah analisis regresi berganda yang digunakan untuk melihat pengaruh faktor-faktor yang mempengaruhi PAD yaitu Produk Domestik Regional Bruto (PDRB) dan jumlah penduduk di Kabupaten Kerinci. Data diolah dengan bantuan software E-Views 8, (Gujarati, 2012)

Model persamaan regresi dalam penelitian ini dengan spesifikasi model dasar sebagai berikut:

\section{$\mathrm{Y}=\mathbf{f}(\mathrm{X} 1 ; \mathrm{X} 2 ; \mathrm{X} 3)$}

Berdasarkan model dasar dapat diformulasikan menjadi persamaan regresi sebagai berikut:

$$
\mathrm{PADt}=\beta 0+\beta 1 \text { PDRBit }+\beta 2 \text { JPit }+ \text { ui }
$$

\section{Uji asumsi klasik}

Berdasarkan hasil regresi, untuk mengambil kesimpulan maka model persamaan harus terbebas dari penyimpangan asumsi klasik. Dalam penelitian ini dikhususkan pada penelaahan gejala normalitas, multikolinearitas, autokorelasi dan heterokedastisitas.

\section{Uji hipotesis}

Uji hipotesis yang digunakan dalam penelitian ini adalah uji $\mathrm{F}$ (uji simultan) dan Uji t (uji parsial). Uji Fdigunakan untuk melihat pengaruh variabel berbas secara bersama-sama terhadap variabel terikat. Sedangkan uji t digunakan untuk melihat pengaruh masing-masing variabel bebas terhadap variabel terikat.

\section{Koefisien determinasi $\left(\mathbf{R}^{2)}\right.$}

Digunakan untuk mengukur pengaruh variabel independen terhadap variabel dependen. $R^{2}$ bernilai antara Nol sampai dengan satu $0 \leq R^{2} \leq 1$ nilai $\left(R^{2}\right)$ kecil berarti kemampuan variabel-variabel independen dalam menjelaskan variasi variabel independen sangat terbatas. Nilai yang mendekati 1 berarti variabel independen memberikan semua informasi yang dibutuhkan untuk memperoleh prediksi variasi model 
dependen. Semakin tinggi nilai koefisisen determinasi maka akan semakin baik pula kemampuan variabel independen dalam menjelaskan variabel dependen.

\section{HASIL DAN PEMBAHASAN}

\section{Perkembangan pendapatan asli daerah Kabupaten Kerinci}

Pendapatan Asli Daerah atau yang sering disebut dengan PAD merupakan pendapatan daerah yang bersumber dari hasil pajak daerah, retribusi, hasil dari pengelolaan kekayaan yang dipisahkan serta pendapatan lainnya yang asli dari daerah dan sah. Perkembangan Pendapatan Asli Daerah (PAD) di Kabupaten Kerinci. Perkembangan Pendapatan Asli Daerah (PAD) di Kabupaten Kerinci mengalami fluktuasi dari tahun 2006 sampai 2020, dimana peningkatan dan penurunannya tidak terlalu signifikan, peningkatan yang terjadi pada periode 2006-2020 tidak mencapai 1 persen dan penurunannya tidak ada yang lebih 1 persen. Rata-rata perkembangan Pendapatan Asli Daerah Kabupaten Kerinci sebesar Rp. 47.220 Juta dengan rata-rata perkembangan pertahunnya sebesar 0,16 persen. Pada tahun 2009 PAD Kabupaten Kerinci mengalami penurunan sebesar 0,06 persen dari Rp. 31.200 Juta pada tahun 2018 mengalami penurunan sebesar Rp. 29.356 Juta pada tahun 2009. Penuruan PAD juga terjadi pada tahun 2012, 2017 dan 2019, pada tahun 2017 PAD turun sebesar 0,07 persen dan pada tahun 2019 mengalami penurunan sebesar 0,47 persen. Perkembangan PAD di Kabupaten Kerinci didorong dari banyaknya pajak dan retribusi di Kabupaten Kerinci. Peningkatan pajak dan retribusi sehingga menimbulkan dampak pada peningkatan PAD di Kabupaten Kerinci.

\section{Perkembangan PDRB Kabupaten Kerinci}

Produk Domestik Regional Bruto (PDRB) adalah nilai dari seluruh barang dan jasa yang diproduksi dalam waktu satu tahun di suatu wilayah tertentu tanpa membedakan kepemilikan faktor produksi, tapi lebih memerlukan keberadaan faktor produksi yang digunakan dalam proses produksi itu, PDRB merupakan salah satu pencerminan kemajuan ekonomi suatu daerah. Kenaikan PDRB akan menyebabkan pendapatan daerah dari sektor pajak dan retribusi meningkat. Perkembangan Produk Domestik Regional Bruto (PDRB).

PDRB Kabupaten Kerinci periode 2006 hingga 2020 mengalami peningkatan dengan rata-rata peningkatannya sebesar 0,13 persen per tahun kecuali pada tahun 2008 menurun 0,22 persen dari tahun 2007. Dan rata-rata PDRB di Kabupaten Kerinci periode 2006-2020 sebesar Rp. 5.907,25 Milyar Peningkatan PDRB di Kabupaten Kerinci didorong dari peningkatan yang terjadi di sektor-sektor yang ada di Kabupaten Kerinci, seperti sektor pertanian sektor industri dan sektor lainnya (BPS, 2020). Sektor pertanian yang merupakan sektor utama di Kabupaten Kerinci memberikan sumbangan kepada PDRB yang cukup tinggi sehingga PDRB di Kabupaten Kerinci juga mengalami peningkatan.

\section{Perkembangan jumlah penduduk Kabupaten Kerinci}

Jumlah penduduk adalah sejumlah orang yang sah mendiami suatu daerah atau negara serta mentaati ketentuan-ketentuan daerah atau negara tersebut. Penduduk merupakan salah satu objek dalam pembangunan, jumlah penduduk dapat mempengaruhi perkembangan dalam perekonomian suatu daerah apabila pertambahan jumlah penduduk 
tidak didukung dengan pertambahan daya tampung dan kualitas penduduk. Sehingga sasaran dalam pembangunan penduduk adalah meningkatakn skill dan kualitas penduduk dan penyebarannya sehinggga tidak ada ketimpangan dalam penduduk dan dapat meningkatkan kesejahteraan untuk penduduk.

Jumlah peduduk di Kabupaten Kerinci mengalami fluktuasi namun tidak signifikan. Perkembangan yang terjadi periode 2006 hingga 2020 sebesar 0,0160 persen, dengan rata-rata jumlah penduduk di Kabupaten Kerinci sebanya 245.932 jiwa. Perkembangan jumlah penduduk pada tahun 2007-2010 mengalami penurunan. Selainnya terus mengalami peningkatan kecuali pada tahiun 2014. Hal ini memperlihatkan bahwa peningkatan jumlah penduduk merupakan modal awal untuk sumber daya manusia di Kabupaten Kerinci jika di di kelola dengan baik. Dengan banyaknya jumlah penduduk yang dikelola dan ditambahkan skill masyarakatnya dengan baik maka potensi dalam pembangunan daerah juga akan membaik karena salah satu faktor dalam mendorong pertumbuhan perekonomian di suatu daerah adalah jumlah penduduknya yang banyak juga skill stau kualitas penduduknya juga baik.

\section{Analisis pengaruh PDRB, jumlah penduduk terhadap pendapatan asli daerah}

Hasil regresi yang didapatkan dari pengolahan dengan menggunakan eviews, diperoleh hasil estimasi sebagai berikut:

Tabel 2. Hasil regresi

\begin{tabular}{cccccc}
\hline Variabel & Koefisien & t-statistik & Probabilita & R-squared & $\begin{array}{c}\text { F Statistik } \\
\text { (Prob) }\end{array}$ \\
\hline C & 40417,61 & 1,156830 & 0,2699 & 0,763040 & 19,32075 \\
PDRB & 6,424474 & 5,315571 & 0,0002 & & \\
JP & $-0,126654$ & $-0,989392$ & 0,3420 & & \\
\hline
\end{tabular}

Sumber. Data diolah, 2021

Dari hasil regres tersebut dapat dirumuskan dalam persamaan berikut:

PAD $=$ 40.417,61+ 6,424474PDRB $-0,126654 \mathrm{JP}$

Keterangan:

PAD = Pendapatan asli daerah

PDRB $=$ Produk domestik regional bruto

$\mathrm{JP} \quad=$ Jumlah penduduk

\section{Uji asumsi klasik}

Hasil uji Normalitas berdasarkan hasil JB diperoleh bahwa nilai JB lebih kecil dari pada $\mathrm{X}^{2}$ Tabel $(8,28<28,86)$, sehingga dapat disimpulkan data berdistribusi normal. Berdasarkan hasil uji Heterokedastisitas Obs*R-squared $<X^{2}$ tabel $(3,95<28,86)$ dapat disimpulkan bahwa data tidak terdapat masalah heterokedastisitas. Uji Autokorelasi Nilai Obs ${ }^{*} \mathrm{R}$-Squared lebih kecil dari $\mathrm{X}^{2}$ tabel $(0,12<28,86)$, maka $\mathrm{H}_{1}$ diterima dan $\mathrm{H}_{0}$ ditolak, kesimpulannya adalah dengan tingkat keyakinan 95 persen, dapat dikatakan bahwa tidak terdapat autokorelasi dalam model regresi.

Tabel 3. Hasil asumsi klasik 


\begin{tabular}{cccc}
\hline Uji Asumsi Klasik & $\begin{array}{c}\text { JB/ Obs*R- } \\
\text { Squared }\end{array}$ & $\mathbf{X}^{\mathbf{2}}$ Tabel & Kesimpulan \\
\hline Normalitas & 8,28 & & $\begin{array}{c}\text { Error term berdistribusi } \\
\text { normal }\end{array}$ \\
Heterokedastisitas & 3,95 & 28,86 & $\begin{array}{c}\text { Tidak terdapat } \\
\text { Heterokedastisitas } \\
\text { Tidak terdapat } \\
\text { Autokorelasi }\end{array}$ \\
Autokorelas
\end{tabular}

Sumber. Data diolah, 2021

Berdasarkan matrik korelasi dari Tabel 4 diperoleh bahwa tidak adanya keterkaitan antar variabel bebas antara PDRB dan jumlah penduduk dengan nilai matrik -0,37. Sehingga dapat disimpulkan bahwa regresi tidak mengalami multikolinearitas karena nilai matrik korelasi tidak terdapat nilai yang lebih dari 0,80. Dari hasil uji asumsi klasik tersebut dapat disimpulkan bahwa penelitian ini terbebas dari asumsi klasi dan bersifat BLUE (best, linear, unbiased, estimator).

Tabel 4. Matrik korelasi multikolinearitas

\begin{tabular}{ccc}
\hline & PDRB & JP \\
\hline PDRB & 1 & $-0,37$ \\
JP & $-0,37$ & 1 \\
\hline
\end{tabular}

Sumber. Data diolah, 2021

\section{Pengujian hipotesis}

Uji F

Dari hasil ouput analisis regresi dapat diketahui nilai $\mathrm{F}$ hitung yaitu sebesar 19,32 dengan probabilitas $\mathrm{F}$ sebesar 0.000 atau lebih kecil dari $\alpha$ pada taraf $=0,05(5 \%)$ dalam hal ini $\mathrm{F}$ hitung $>\mathrm{F}$ tabel ( $\mathrm{F}$ hitung 19,32 > F tabel 3,10) yang artinya semua variabel bebas secara bersama-sama mempunyai pengaruh terhadap variabel terikat. Sehingga hasil ini menyatakan bahwa variabel PDRB dan jumlah penduduk secara bersama-sama (simultan) berpengaruh terhadap pendapatan asli daerah di Kabupaten Kerinci. Hasil tersebut membuktikan bahwa dari kedua variabel bebas (PDRB dan Jumlah penduduk) memiliki keterkaitan yang penting terhadap peningkatan Pendapatan Asli Daerah di Kabupaten Kerinci. Sehingga dugaan terhadap adanya pengaruh yang signifikan terhadap PAD di Kabupaten kerinci terbukti benar.

\section{Uji t (uji parsial)}

Nilai Contanta sebesar 1,1568, artinya apabila semua variabel bebas (PDRB dan jumlah penduduk memiliki nilai 0 atau tidak mengalami perubahan dari PDRB dan jumlah penduduk maka Pendapatan Asli Daerah di kabupaten kerinci meningkat sebesar 1,1568 .

Variabel PDRB berpengaruh terhadap Pendapatan Asli Daerah. Berdasarkan perbandingan nilai dari t-hitung dan t-tabel. T-hitung yang diperoleh nilainya lebih besar dari pada nilai t-tabel $(5,3155>1,73)$ serta probabilita dari variabel PDRB yang didapatkan 0,0002 yang lebih kecil dari 0,05 tingkat alfa signifikansi. Artinya secara parsial PDRB berpengaruh terhadap variabel dependen (PAD). Kemudian tanda yang didapatkan dari hasil regresi untuk variabel PDRB adalah positif, yang artinya setiap 
terjadi kenaikan PDRB sebesar Rp. 1 Milyar maka pendapatan asli daerah di Kabupaten Kerinci mengalami peningkatan sebesar Rp. 6,4244 Milyar.

Variabel jumlah penduduk tidak berpengaruh signifikan terhadap pendapatan asli daerah. t-hitung yang diperoleh dari hasil output regresi memiliki nilai yang lebih kecil dari t-tabel. $(0,9893<1,73)$ serta nilai probabilita dari variabel jumlah tenaga kerja yang lebih besar dari tingkat signifikansi alfa 5 persen. $(0,3420>0,05)$. Artinya secara parsial jumlah penduduk tidak berpengaruh signifikan terhadap variabel dependen (PAD).

\section{Koefisien determinasi $\left(\mathbf{R}^{2}\right)$}

Didapatkan hasil $\mathrm{R}^{2}$ sebesar 0,7630 atau sebesar 76,30 persen. Hal ini menunjukan bahwa kemampuan variabel PDRB dan jumlah penduduk dalam menjelaskan variabel pendapatan asli daerah (PAD) sebesar 76,30 persen sedangkan sisanya sebesar 23,70 persen dijelaskan oleh variabel lain yang tidak diteliti atau dijelaskan dalam penelitian ini.

\section{Interpretasi secara ekonomi}

\section{Pengaruh PDRB terhadap pendapatan asli daerah (PAD)}

PDRB merupakan nilai pasar yang di produksi oleh suatu daerah pada periode tertentu. Hasil penelitian menunjukan bahwa PDRB memiliki pengaruh signifikan terhadap pendapatan asli daerah di Kabupaten Kerinci. Hal ini sesuai dengan penelitian yang dilakukan oleh Iman (2019) bahwa variabel PDRB memiliki pengaruh yang signifikan terhadap pendapatan asli daerah di Kabupaten Bandung, dan juga penelitian yang dilakukan oleh Prana (2016) yang menyatakan bahwa periode 2001-2012 PDRB memiliki pengaruh yang signifikan terhadap PAD di Kota Tebing Tinggi.

Dari data yang diperoleh menunjukan bahwa PDRB di Kabupaten Kerinci terus mengalami peningkatan walaupun peningkatan yang terjadi belum terlalu signifikan. Namun peningkatan yang ada pada PDRB membuktikan bahwa pendapatan asli daerah di Kabupaten kerinci dipengaruhi oleh PDRB dengan terlihat dari meningkatnya pendapatan asli daerah pada periode tersebut. Peningkatan yang terjadi di PDRB tentu didorong dengan masuknya investor-investor untuk berinvestasi di Kabupaten Kerinci, sehinggga dengan banyaknya investasi yang masuk maka pendapatan daerah juga meningkat terutama PDRB. PDRB di Kabupaten Kerinci didorong oleh satu pertanian kemudian mulai banyaknya kegiatan industri adan pariwisata serta hotel di Kabupaten Kerinci. Jaya (2014) menjelaskan bahwa dengan adanya peningkatan PDRB maka akan menunjukan adanya dorongan dalam meningkatkan Pendapatan Asli Daerah (PAD). Sehingga diperlukan peran pemerintah dalam peningkatan PDRB baik sektor pertanian maupun sektor industri. Yang akan berdamapak pada peningkatan PAD dan kesejahteraan masyarakat sekitar.

\section{Jumlah penduduk terhadap pendapatan asli daerah (PAD)}

Jumlah Penduduk adalah sejumlah orang yang sah menurut hukum tinggal di suatu daerah atau negara yang mematuhi ketentuan yang ada disuatau daerah/negara yang mereka huni. Hasil olahan regresi dalam penelitian ini menunjukan bahwa jumlah penduduk tidak memiliki pengaruh yang signifikan terhadap pendapatan asli daerah di Kabupaten Kerinci. Hal ini berbeda dengan teori yang dikeluarkan oleh Simanjutak (2011) yang menyatakan bahwa menyatakan bahwa jumlah penduduk yang meningkat 
maka pendapatan yang ditarik juga meningkat. Karena penduduk merupakan sumber daya utama dalam pergerakan perekonomian suatu daerah/negara. Namun sesuai dengan penelitian yang dilakukan oleh Pewira pada tahun 2018 di Sulawesi Tengah, iya menyatakan bahwa jumlah penduduk tidak memiliki pengaruh yang signifikan terhadap pendapatan asli daerah di Sulawesi Tengah.

Hal ini disebabkan karena peningkatan jumlah penduduk di Kabupaten Kerinci tidak didorong dengan peningkatan kualitas hidup penduduk tersebut. Sehingga pendapatan asli daerah tidak dipengaruhi oleh peningkatan penduduk di Kabupaten kerinci. Selain itu rata-rata penduduk di Kabupaten Kerinci masih bekerja di sektor pertanian sehingga peran penduduk masih banyak di perkembangan sektor dibanding pendapatan asli daerah.

\section{KESIMPULAN DAN SARAN}

\section{Kesimpulan}

Perkembangan Pendapatan Asli Daerah (PAD) di Kabupaten Kerinci mengalami peningkatan kecuali tahun 2009, 2012, 2017 dan 2019 dengan rata-rata PAD sebesar Rp. 47.220 Juta pertahun, perkembangan PDRB di Kabupaten Kerinci mengalami peningkatan secara terus menerus kecuali tahun 2008 dengan rata-rata PDRB sebesar Rp. 5.907,25 Milyar pertahun dan perkembangan jumlah penduduk di Kabupaten Kerinci rata-rata sebesar 245.932 jiwa pertahun.

Hasil analisis faktor yang mempengaruhi pendapatan asli daerah di Kabupaten Kerinci, PDRB dan jumlah penduduk secara bersama-sama berpengaruh signifikan terhadap Pendapatan Asli Daerah (PAD) di Kabupaten Kerinci. Secara parsial PDRB berpengaruh terhadap PAD, sedangkan variabel jumlah penduduk tidak berpengaruh signifikan.

\section{Saran}

Diharapkan kepada pemerintah Kabupaten Kerinci terus memperhatikan peningkatan PDRB di Kabupaten Kerinci sebagai salah satu variabel yang memiliki pengaruh terhadap pendapatan asli daerah Kabupaten Kerinci. Dan memberikan pengetahuan tambahan kepada penduduk Kabupaten Kerinci dari pentingnya faktorfaktor lainya agar menjadi masyarakat yang produktif sehingga bertambahnya jumlah penduduk memberikan dampak yang positif kepada PAD di Kabupaten Kerinci.

Kepada peneliti selanjutnya diharapkan menambahkan variabel-variabel lainya sehingga dapat lebih mendetail dalam memberikan kontribusi terhadap PAD di Kabupaten Kerinci.

\section{DAFTAR PUSTAKA}

Baldric, Siregar. (2017). Akuntansi sektor publik: akuntansi keuangan pemerentiah daerah berbasis aktual. UPPM STIM: Yogyakarta.

Badan Pusat Statistik. (2020). Provinsi Jambi Dalam Angka 2011-2017. BPS Provinsi Jambi: Jambi

Carunia, Mulya. (2017). Kebijakan dan Strategi Peningkatan Pendapatan Asli Daerah dalam Pembangunan Daerah. Yayasan Pustaka Obor Indonesia.

Darise, Nurlan. (2006). Pengelolaan keuangan daerah. Indeks: Jakarta

Gujarati. (2012). Dasar-dasar Ekonometrika. Salemba Empat: Jakarta 
Hartanto, Indrajati \& Jaka.(2011). Sumber pendapatan asli daerah Kabupaten dan Kota. Jurnal Ekonomi dan Studi Pembangunan, 12(1)

Jaya, Gde \& Widanta. (2014). Analisis faktor-faktor yang berpengaruh terhadap pendapatan asli daerah (PAD) Kota Denpasar. Jurnal Ekonomi Pembangunan, $3(5), 173-226$

Makdalena, F dkk. (2015). Pengaruh Pendapatan dan Jumlah Penduduk terhadap Pendapatan Asli Daerah (PAD) di Kota Sorong. Jurnal Berkala Ilmiah Efisiensi, 15(5), 727-737.

Prana, Riandani. (2016). Analisis faktor-faktor yang mempengaruhi pendapatan asli daerah (PAD) Kota Tebing Tinggi. Jurnal Ilmu Manajemen, 4(1),

Simanjuntak, Payaman. (2002). Pengantar ekonomi sumber daya manusia. FE UI: Jakarta.

Sukirno, Sadono. (2006). Mikro ekonomi: teori pengantar. Raja Grafindo: Jakarta

Devita,Andri.,Arman,Delis \& Junaidi.(2014).Pengaruh pendapatan asli daerah, dana alokasi umum dan jumlah penduduk terhadap belanja daerah kabupaten/kota di Provinsi Jambi. Jurnal Perspektif Pembiayaan dan Pembangunan Daerah. 2(2), 63-70

Z Zamzami, D Hastuti. (2018).Determinan penerimaan daerah dan pertumbuhan ekonomi terhadap pengembangan ekonomi kreatif di Provinsi Jambi, Jurnal Paradigma Ekonomika .13 (1), 37-45 